\title{
From anaerobic to aerobic treatment: upcycling of digestate as a moisturizing agent for in-vessel composting process
}

\author{
Nour El Houda Chaher ${ }^{1,2,3^{*}}$ D, Safwat Hemidat ${ }^{3}$, Mehrez Chakchouk ${ }^{2}$, Abdallah Nassour ${ }^{3}$, Moktar Hamdi $^{2}$ \\ and Michael Nelles ${ }^{3,4}$
}

\begin{abstract}
In Tunisia, there are crucial challenges facing both urban and rural areas, the most prominent of which are the production of organic waste, the need for waste treatment, the demand for water and energy and the need for a circular economy. To this end, the study was designed to develop a technical concept on closed cycle 'biowaste to bioenergy' treating, basically food waste (FW) through combined biological processes. In this approach, the generated digestate from FW anaerobic reactors was used successfully as a moisturizing agent for FW in-vessel composting. Four types of digestate were examined to be used as moisturizing agent (MA). The selection of the appropriate MA was achieved based on technical criteria; moisture content (MC), C:N ratio and heavy metals concentrations. The findings showed that the digestate obtained from anaerobic co-digestion of food waste and wheat straw (D1) was the most efficient AD-effluent to be added. In terms of composting process performance, the thermophilic phase of the amended reactor (A1) lasted 16 days and reached higher temperatures of about $72^{\circ} \mathrm{C}$, while the unamended one (A1) was characterized by a thermophilic temperature of around $66^{\circ} \mathrm{C}$ indicating that the end products were of a pathogenfree compost. When it comes to the physico-chemical factors examined demonstrating that the biological conditions were sufficiently developed. The findings showed overall decreasing profiles during the composting period for moisture, C:N ratio as well as nitrification index (NI). From the quality-point of view, it was found that heavy metal concentrations had lower limits than those values set by German standards. Moreover, all the compost samples appeared to be stable and classified as class IV and V end product.
\end{abstract}

Keywords: Biological treatment, Food waste, Digestate, Moisturizing agent, Compost, European standards, End product quality

\section{Introduction}

Urban solid waste management is one of the most pressing and serious environmental problems facing urban governments in developing countries. This challenge will become even more severe in the future given the trends of rapid urbanization and the growth in the urban population (Arafat et al. 2015; Ferronato and Torretta 2019).

\footnotetext{
*Correspondence: nour.chaher@uni-rostock.de

${ }^{1}$ Department of Chemical and Process Engineering, National Engineering

School of Gabes, University of Gabes, 6029 Gabes, Tunisia

Full list of author information is available at the end of the article
}

Improper collection and disposal of waste poses a serious health risk to the population causing a clear environmental degradation in most cities of the developing world (Meylan et al. 2018). With increasing public pressure and environmental legislation, waste experts are being called in to develop more sustainable methods of dealing with municipal waste (Abbasi and Gajalakshmi 2015; Abu Hajar et al. 2020). One of the steps in improving the current situation of solid waste is to enhance resource recovery activities. Recycling of inorganic materials from municipal solid waste is often well developed by the activities of the informal sector (Aparcana 2017). 
However, the reuse of organic waste materials, which often contributes more than $50 \%$ of the total amount of waste, is still limited but has an interesting recovery (Ardolino et al. 2020). Combined approaches to reduce reliance on landfills as a method of disposal and biological treatment is increasingly becoming a standard requirement for the vast majority of biodegradable waste (Bhatia et al. 2018).

Among all management options for organic waste, composting is the most approved method (Ardhaoui et al. 2019). It is an effective strategy to divert solid waste (SW) from landfills and improve the heating value of feedstock in case of energy recovery (Carabassa et al. 2020). Previous studies confirmed that composting reduces the volume of organic materials by more than 30\% (Awasthi et al. 2020) and converts waste into a hygienic and valuable product ( Chaher et al. 2020b; ChenYu et al. 2018).

Availability and variety of raw input materials, less of prerequisites, ease of technology, simplicity of concept, the environment and socio-economic benefits create a great opportunity in Tunisia to produce compost from organic waste (Aydi, 2015; Mahjoub et al. 2020). However, the opportunity to use the different types of organic waste as compost requires scientific studies that endorse it to guide users concerning the aspects behind the better management of the composting operation. In conjunction with the quantitative and life cycle-based evaluations, a comprehensive technical-scientific view of bio-waste composting should also include increasing the currently limited knowledge of the process performance in terms of monitoring and controlling the crucial factors affecting the efficiency of the composting units (Asadu et al. 2019; Chaher et al. 2020a). In this context, moisture content (MC) is a critical factor in the composting process. The optimal MC for effective composting depends on the specific physico-chemical properties and biological features of the materials to be composted (Kim et al. 2016; Xu et al. 2020). However, the optimum $\mathrm{MC}$ required for biological activity during composting is between 50 and 60\%; Chaher et al. 2020b; Hemidat et al. 2018).

Several studies confirmed that moisture content has a remarkable effect on the composting process (Al-Bataina et al. 2016; Barthod et al. 2018; Du et al. 2018; Tibu et al. 2019). It influences the oxygen uptake rate, free air space, microbial activity and the temperature of the process. During composting, the $\mathrm{MC}$ is vital for the distribution of soluble nutrients needed for the microbial metabolic activity (Fan et al.2019). According to Xu et al. (2020) loss of moisture during the composting process can be counted as a strong indication of the decomposition rate. Very low MC could cause early dehydration during composting and that may hinder the biological process and slow down microbial activity under the low moisture range (Franke-Whittle et al. 2014).

It is well known that compost production is a very water-consuming process, as ensuring the required level of moisture requires large quantities of water. Many studies have claimed that every ton of ready-made compost needs $1 \mathrm{~m}^{3}$ of water, and this is a significant amount that should be taken into account when planning such projects, especially in countries that suffer from water scarcity (Bacenetti, 2020; ChenYu et al. 2018; Tibu et al. 2019. Tunisia is one of those countries; it is considered one of the countries in the world with the scarcest water resources (Abdulrahman 2018; Ardhaoui et al. 2019). Tunisia is a water-stressed country with per capita renewable water availability of $486 \mathrm{~m}^{3}$-well below the average of $1200 \mathrm{~m}^{3}$ /capita for the Middle East and North Africa Region (MENA) regions (Jemai et al. 2013). Indeed, the rapidly increasing population began to use more water than the country could provide (Mahjoub et al. 2020).

Therefore, there is an urgent need to seek an alternative to conventional water resources to be used in aerobic composting to ensure the required level of moisture content for an efficient composting process. To reduce the use of conventional water resources during the composting treatment, the research work aims to exploit an unconventional one; digestate produced from food waste (FW) anaerobic digesters to feed FW aerobic digesters. This option might be of considerable value by providing high-acclimated microbial diversity as well as micro- and macro-nutrients to enhance the process performance and the end product quality. A further objective is to examine its effect on FW in-vessel composting treatment as a moisturizing agent (MA).

\section{Overall concept}

The research work was launched in the framework of "RenewValue project" aiming to optimize the exploitation of different types of biowastes: food waste (FW), wheat straw (WS) and cattle manure (CM). The overall concept followed in the project is illustrated in Fig. 1.

The study aimed to recover the AD-effluents derived from anaerobic digesters treating mainly food waste. To this end, the experimental work was fundamentally divided into two phases. During the first one, the input materials (FW, WS, CM) were subjected to anaerobic digestion (AD), while the second phase was assigned to examine the exploitation of the digestate residue; from a by-product of the anaerobic treatment to feedstock for aerobic process which is the main target of the current study.

In this approach, the different pre-sorted bio-waste materials were processed to digestate and compost. In the first place, organic waste was converted into biogas 


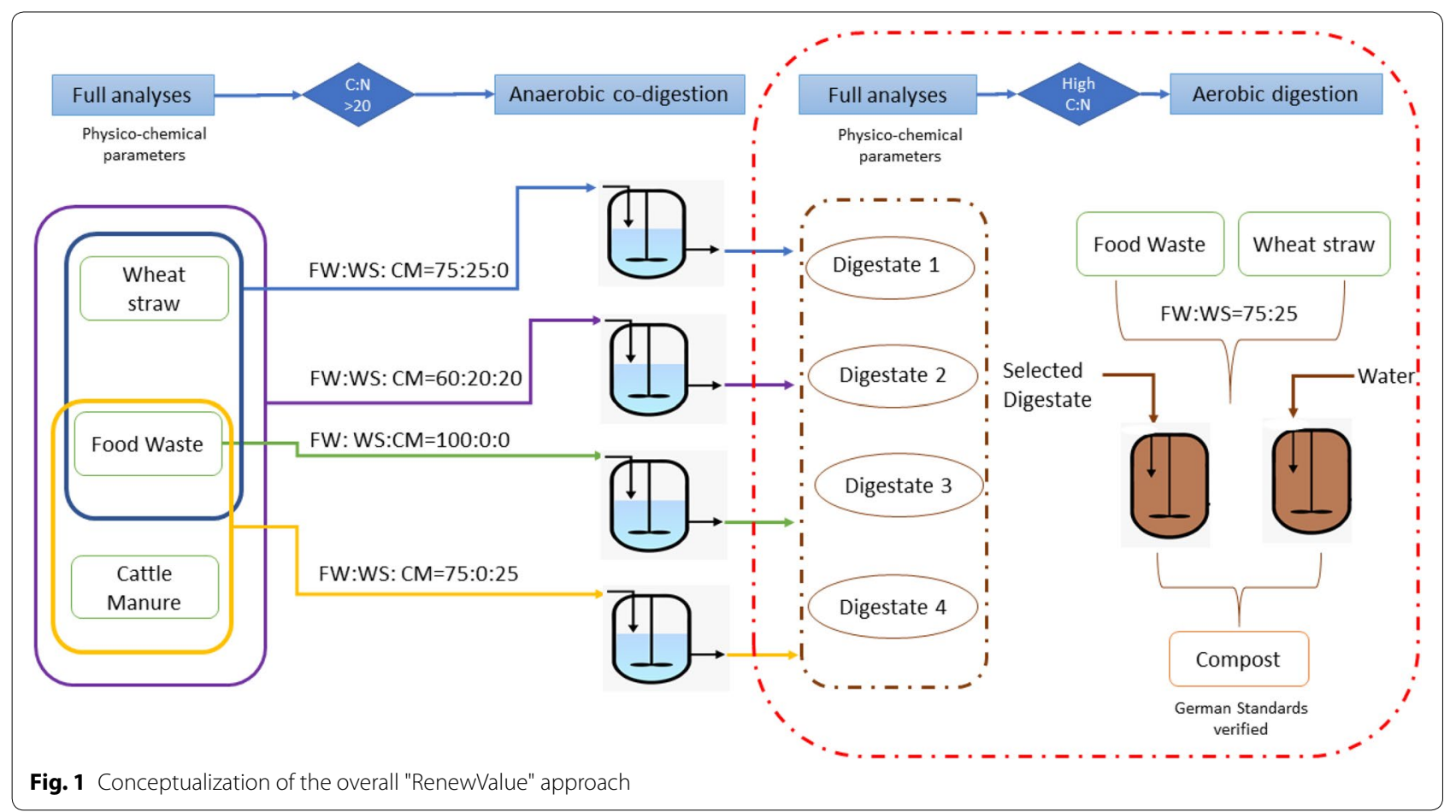

and digestate. The latter was then exploited as a moisturizing agent (MA) for food waste and wheat straw in-vessel composting. Over the experimental work, the different organic residues were subjected to several processes such as conditioning, mixing, sampling and analysis.

\section{Materials and methods}

\section{Anaerobic digestion}

Different substrates-mixtures were prepared to feed, twice per day to feed eight (8) anaerobic reactors with a capacity of $20 \mathrm{~L}$. Once the anaerobic treatment was accomplished, the generated digestates were collected to be fully characterized (Table 1). In addition, a comparison

Table 1 Physico-chemical characterization of the collected digestates

\begin{tabular}{|c|c|c|c|c|c|c|}
\hline Parameters & Units & D1 & D2 & D3 & D4 & $\begin{array}{l}D_{1} \text { (Stoknes } \\
\text { et al. 2016) }\end{array}$ \\
\hline $\mathrm{pH}$ & - & 7.49 & 7.51 & 7.02 & 8.13 & - \\
\hline Moisture content (MC) & $\%$ of FM & 96.70 & 95.90 & 97.50 & 97.30 & 97.60 \\
\hline Carbon (C) & $\%$ of FM & 37.60 & 35.20 & 40.10 & 37.20 & - \\
\hline Nitrogen (N) & $\%$ of FM & 2.90 & 3.70 & 4.70 & 4.40 & 10 \\
\hline C:N ratio & - & 12.97 & 9.51 & 8.53 & 8.45 & - \\
\hline Phosphors (P) & $\%$ of TS & 3.02 & 3.17 & 2.87 & 2.91 & 1.00 \\
\hline Potassium (K) & $\%$ of TS & 4.16 & 4.04 & 4.21 & 4.86 & 4.00 \\
\hline Lead (Pb) & $\mathrm{mg} / \mathrm{kg} \mathrm{TS}$ & 2.33 & 2.46 & 2.29 & 2.54 & 0.43 \\
\hline Copper (Cu) & $\mathrm{mg} / \mathrm{kg}$ TS & 38.86 & 46.02 & 44.07 & 60.02 & - \\
\hline $\operatorname{Zinc}(Z n)$ & $\mathrm{mg} / \mathrm{kg} \mathrm{TS}$ & 165.64 & 185.07 & 167.65 & 223.41 & 75.00 \\
\hline Nickel (Ni) & $\mathrm{mg} / \mathrm{kg}$ TS & 8.08 & 7.24 & 6.48 & 9.00 & 225 \\
\hline Cadmium (Cd) & mg/kg TS & 0.32 & 0.40 & 0.35 & 0.38 & 8.94 \\
\hline Arsenic (As) & mg/kg TS & 1.40 & 1.95 & 1.70 & 1.76 & 0.14 \\
\hline Mercury (Hg) & $\mathrm{mg} / \mathrm{kg}$ TS & 0.02 & 0.05 & 0.07 & 0.09 & - \\
\hline
\end{tabular}

FM fresh matter, TS total solids, $D_{1}$ digestate collected from mesophilic anaerobic digesters treating FW (Stoknes et al. 2016) 
between the digestate properties examined during the current work and the results achieved by Stoknes et al. (2016) also treating food waste was performed.

Four types of digestates were generated and a detailed analysis was conducted for each; physico-chemical properties, macro- and micro-nutrients as well as the heavy metals contents were examined. Accordingly, selection criteria were developed. The latter were designed with regard to the main factors affecting the composting process performance as well as the end product quality. As a result, moisture content (MC) and $\mathrm{C}: \mathrm{N}$ ratio were considered as steering parameters, while, in the second place, heavy metal (HMs) contents were given a lower priority as the four categories of digestates produced had HMs concentrations lower than the limits set by German Standards.

All the produced digestates met the technical specifications in terms of moisture content and HMs concentrations. However, the feedstock mixture prepared from FW:CM:WS $=75: 25: 0$ and FW:CM:WS $=60: 20: 20$, had a significant effect on the AD-liquid effluent characteristics. Indeed, digesters, including enriched nitrogenous components such as manure, were characterized by a lower C:N ratio, which is the case of D3 and D4. Moreover, the latter were influenced by the contribution of manure in terms of heavy metals (HMs); relatively high concentration compared to the rest.

\section{Aerobic digestion Raw materials}

During the experimental work, FW was considered as the main substrate for the in-vessel composting process. FW was gathered from the canteen of the University of Rostock, Germany. It mostly consisted of pasta, salad, a small amount of meat and cooked potatoes. Once collected, it was conserved in small containers and stored at $-20{ }^{\circ} \mathrm{C}$ to avoid any microbiological reaction. As a potential cosubstrate, wheat straw (WS) was gathered from a farm in the vicinity of Rostock, after that the WS was chopped $(<10 \mathrm{~mm})$ and stored in plastic airtight buckets kept at an ambient temperature. WS was selected to be added at a rate of $25 \%$ of the total fresh mass used referring to a previous research work (Chaher et al. 2020a). Further, mature compost $(\mathrm{Mc})$ that was obtained from a local composting plant treating garden waste was used as a bulking agent (BA) to ensure the requested porosity and to sustain air spaces for oxygen transfer.

In addition to the oxygen supply, a performant aerobic treatment was ensured by a sufficient rate of moisture content (MC), an adjusted C:N ratio and an initial source of acclimated microorganisms. The amendment of composters with acclimatized digestate (D) aimed to save the amount of water to be added during the biodegradation of the organic materials and evaluate the effects of this on the process performance and the end product quality (Franke-Whittle et al. 2014).

\section{Experimental setup}

A 200-L laboratory-scale composter was used during the experimental work (Fig. 2). The composter is a stainless-steel vessel of a nominal inside diameter of around $700 \mathrm{~mm}$ and covered by a heat insulation layer to minimize heat losses. The airflow distribution is ensured by a metal grid with small holes fixed at the bottom of the vessel. The airflow was manually regulated during composting using a gas flow meter. Regarding the leachate collection, it was achieved by a fixed valve at the conical bottom of the composter. For the temperature monitoring, temperature sensors (TIR1) and (TIR2) were attached at different depths to monitor the fluctuation of the compost temperature. Both the compost temperature and the ambient temperature variations were automatically logged every 10 min using ALMEMO ${ }^{\circledR}$ data logger system (Ahlborn, German).

Two experimental trials were carried out to evaluate the impact of digestate addition on in-vessel FW composting. The composter was filled with around $55 \mathrm{~kg}$ of fresh matter. As a blank test, FW and WS co-composting without any amendment (A1) was firstly conducted in duplicate, then A2 was carried out to evaluate the digestate addition effects. Before feeding the composter, organic materials, including the bulking agent, were manually mixed and then the moisturizing agent (MA) was added. The moisture content of the initial starting material was adjusted to be in the requested range of $55-65 \%$ using water for the A1 test and digestate for A2. As the maintenance of $\mathrm{MC}$ at a certain range during

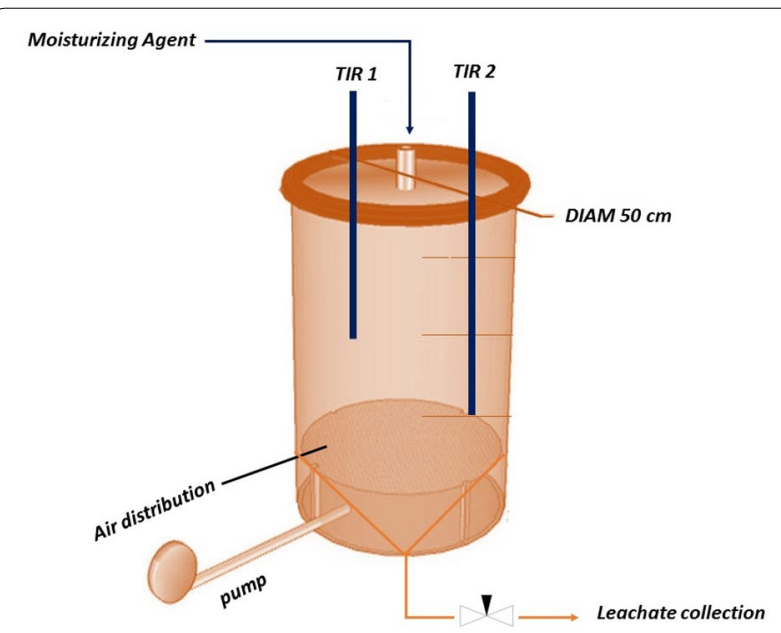

Fig. 2 Scheme of the in-vessel composter 
the composting process is crucial, the amount of MA to be added (in litres) was determined to compare the consumption of digestate and water. Table 2 displays the trial ingredients and composting time.

\section{Sampling and analysis}

During the 9 weeks of the experimental work, sampling was achieved at regular intervals to evaluate the composting process evolution. Weekly, three representative samples were taken and were either analysed directly or stored $\left(4{ }^{\circ} \mathrm{C}\right.$ and $\left.-20{ }^{\circ} \mathrm{C}\right)$ for future analyses. Different parameters were determined in triplicate; moisture content $(\mathrm{MC})(\%)$, total carbon (TC), total nitrogen (TN), $\mathrm{pH}$, electrical conductivity (EC), total solid (TS) (\%) and mineral nitrogen content, such as ammonium $\left(\mathrm{NH}_{4}{ }^{+}\right)$ and nitrate $\left(\mathrm{NO}_{3}{ }^{-}\right)$, were monitored (Table 3$)$. However, to follow-up the stability and maturity of the compost, respiration activity $\left(\mathrm{AT}_{4}\right)$ was identified at the end of the process. To assess the quality of the end product, heavy metals contents (HMs) were, in addition, measured to be compared to quality requirements for the compost of several countries with regard to $\mathrm{Pb}, \mathrm{Cu}, \mathrm{Ni}, \mathrm{Zn}, \mathrm{Cd}, \mathrm{Cr}$, $\mathrm{Hg}$ and As concentrations. All the experimental protocols carried out were described in detail in a previous work.

\begin{tabular}{lllll}
$\begin{array}{l}\text { Table } 2 \text { Compost } \\
\text { of the process }\end{array}$ & runs ingredients and & duration \\
\hline Trials & $\begin{array}{l}\text { Raw input } \\
\text { material }\end{array}$ & Moisturizing agent & $\begin{array}{l}\text { Initial } \\
\text { weight } \\
\text { (kg) }\end{array}$ & $\begin{array}{l}\text { Duration } \\
\text { (days) }\end{array}$ \\
\hline A1 & FW:WS & Water & 54 & 36 \\
A2 & FW:WS & Digestate & 56 & 36 \\
\hline
\end{tabular}

\section{Results and discussion}

Physicochemical characteristics of the organic materials The properties of the raw organic materials used are presented in Table 4 . The moisture content was $77.4 \%, 6.5 \%$, $53.3 \%$, and $96.7 \%$ for FW, WS, Mc and D, respectively. To meet the required range of $\mathrm{MC}$, which is $55-65 \%$, a moisturizing agent (MA) was added to each mixture to regulate the $\mathrm{MC}$ of $\mathrm{A} 1$ to $\mathrm{A} 2$ at $65.8 \%$ and $68.7 \%$, respectively. The initial C:N ratio was examined for each substrate to

\begin{tabular}{|c|c|c|c|c|c|}
\hline Parameters & Units & FW & WS & Mc & D \\
\hline $\mathrm{pH}$ & - & 4.22 & - & 7.80 & 7.49 \\
\hline Conductivity (EC) & $(\mathrm{mS} / \mathrm{cm})$ & 5.71 & - & 3.29 & - \\
\hline Moisture content (MC) & $\%$ of FM & 77.40 & 6.50 & 53.30 & 96.7 \\
\hline Total solids (TS) & $\%$ of FM & 22.60 & 93.50 & 46.70 & 3.30 \\
\hline Carbon (C) & $\%$ of FM & 47.7 & 47.63 & 22.50 & 37.60 \\
\hline Nitrogen (N) & $\%$ of FM & 2.60 & 0.61 & 1.60 & 2.90 \\
\hline C:N ratio & & 18.35 & 78.08 & 14.06 & 12.97 \\
\hline Phosphors (P) & $\%$ of TS & 0.48 & 0.06 & 0.52 & 3.02 \\
\hline Potassium (K) & $\%$ of TS & 0.91 & 1.74 & 1.12 & 4.16 \\
\hline Magnesium (Mg) & $\%$ of TS & 0.09 & 0.25 & 1.22 & 2.33 \\
\hline Lead (Pb) & $\mathrm{mg} / \mathrm{kg}$ TS & 0.91 & 0.21 & 20.63 & 38.86 \\
\hline Copper (Cu) & $\mathrm{mg} / \mathrm{kg}$ TS & 6.82 & 1.78 & 23.30 & 165.64 \\
\hline $\operatorname{Zinc}(Z n)$ & $\mathrm{mg} / \mathrm{kg} \mathrm{TS}$ & 16.33 & 16.6 & 143 & 8.08 \\
\hline Nickel (Ni) & $\mathrm{mg} / \mathrm{kg}$ TS & 0.95 & 5.78 & 9.34 & 0.32 \\
\hline Cadmium (Cd) & $\mathrm{mg} / \mathrm{kg}$ TS & 0.07 & 0.08 & 0.26 & 1.40 \\
\hline Arsenic (As) & $\mathrm{mg} / \mathrm{kg}$ TS & 0.57 & 0.07 & 3.10 & 0.02 \\
\hline Mercury (Hg) & $\mathrm{mg} / \mathrm{kg}$ TS & $<0.01$ & $<0.01$ & 0.02 & 0.05 \\
\hline
\end{tabular}

FM fresh matter, TS total solids

Table 3 Physical and chemical parameter measurement of composting parameters and their corresponding standard methods

\begin{tabular}{|c|c|c|c|}
\hline Parameter & Frequency & Method & References \\
\hline Moisture content (MC) & Each 5 days & Using electronic oven by drying at $105^{\circ} \mathrm{C}$ for $24 \mathrm{~h}$ & NF ISO 11465 (1994) \\
\hline Conductivity (EC) & Each 5 days & 1:10 w/v sample: water extract & NF ISO 11265 (1995) \\
\hline $\mathrm{pH}$ & Each 5 days & & ISO 10390 (1994) \\
\hline Total organic carbon (TOC) & Each 5 days & $\mathrm{TOC}(\%)=((100-$ Ash $\%) \div 1 / 8)$ & (Wang et al. 2018) \\
\hline Total nitrogen (TN) & Each 5 days & Titrimetric methods & NF ISO 11265 (1995) \\
\hline C:N ratio & Each 5 days & Expressed as ratio of (TOC/TKN) \% & Wang et al. (2018) \\
\hline $\mathrm{NH}_{4}^{+}$ & Each five days & 1:5 w/v sample: water extract & NF ISO 11048 \\
\hline $\mathrm{NO}_{3}^{-}$ & Each 5 days & Ion chromatography & NF EN 10304-1 \\
\hline Nitrification index & Each 5 days & Expressed as ratio of $\left(\mathrm{NH}_{4}^{+}: \mathrm{NO}_{3}^{-}\right)$ & Chaher et al. (2020a) \\
\hline Total $P$ and $K$ & Start and end & Atomic absorption spectrometric methods & ISO 11885 (2007) \\
\hline Respiration activity $\left(\mathrm{AT}_{4}\right)$ & At the end & $\mathrm{CO}_{2}$ consumption by $\mathrm{NaOH}(1 \mathrm{~N})$ & DIN ISO 16072 \\
\hline Heavy metals & At the end & $\begin{array}{l}\text { Inductively coupled plasma-mass spectrometer, thermo- } \\
\text { elemental ICP-MS-X series }\end{array}$ & ISO 11885 (2007) \\
\hline
\end{tabular}


ensure the required carbon to nitrogen rate demanded by microorganisms for an efficient biological degradation of the organics. Several studies reported that the appropriate initial C:N ratio of the feedstock ranged between 20 and 40 (Kumar et al. 2010; Tibu et al. 2019; Xu et al. 2020), which was achieved for both A1 and A2 to be around 33.28 and 31.07 , respectively. Additionally, heavy metals and trace elements content were identified. Moreover, several physico-chemical characteristics, such as $\mathrm{pH}$, conductivity (EC), potassium (K), phosphorus $(\mathrm{P})$ as well as heavy metals, were investigated in order to guarantee an efficient development of the process.

\section{Temperature monitoring profile during the composting process}

Temperature is one of the most important factors governing the composting process. Therefore, the temperature evolution was monitored regularly to ensure efficient microbial activity and decomposition rate. As is evident from Fig. 3, which shows the temperature trends for different trials, three phases of the aerobic process were achieved (Torres-Climent et al. 2015). The modified reactor (A2) detected a rapid temperature rise during the second day, reaching $72{ }^{\circ} \mathrm{C}$ as the maximum temperature during the 16-day thermophilic phase. However, the A1 temperature profile was slightly different in terms of the highest temperature reached, as well as the duration of the thermophilic phase. The first temperature peak, which announced the onset of the thermophilic step, was recorded on day 5 , while the second peak was marked with an ideal temperature of $66{ }^{\circ} \mathrm{C}$ on day 9 to drop to mesophilic temperature after 14 days. The thermophilic phase duration of both A1 and A2 met the criteria for obtaining pathogen-free compost according to BioAbfV (1998) which indicated that temperatures should be above $55{ }^{\circ} \mathrm{C}$ for at least 14 continuous days. Accordingly, the produced compost was considered hygienically acceptable.

By comparing temperature trends, the modified reactor accomplished the thermophilic phase faster with longer duration and higher temperature values which, in turn, emphasized the importance of adding digestate to the FW in-vessel composting process. Addition of ADeffluent had a significant effect in speeding up the heating of the composted material by providing an effective acclimatized inoculum. Similar findings were reported by Akyol et al. (2019) revealing that the fluctuation of temperature was a direct result of the enhanced microorganisms' activity. Therefore, the addition of a suitable microbial community served as a composting booster (Casini et al. 2019). Afterwards, the temperatures of the different trials decreased sharply, until a fixed set of values reached the ambient temperature, which announced the start of the cooling phase. Therefore, no significant degradation was achieved during the stabilization phase (from day 21 until the end of the process), while organic humification occurred at the same time (Li et al. 2017). The findings obtained are in line with several studies that confirmed the significant effect of adding digestate on temperature progression during the composting process (Al Seadi et al. 2013; Stoknes et al. 2016; Torres-Climent et al. 2015). However, assuming that the digestion

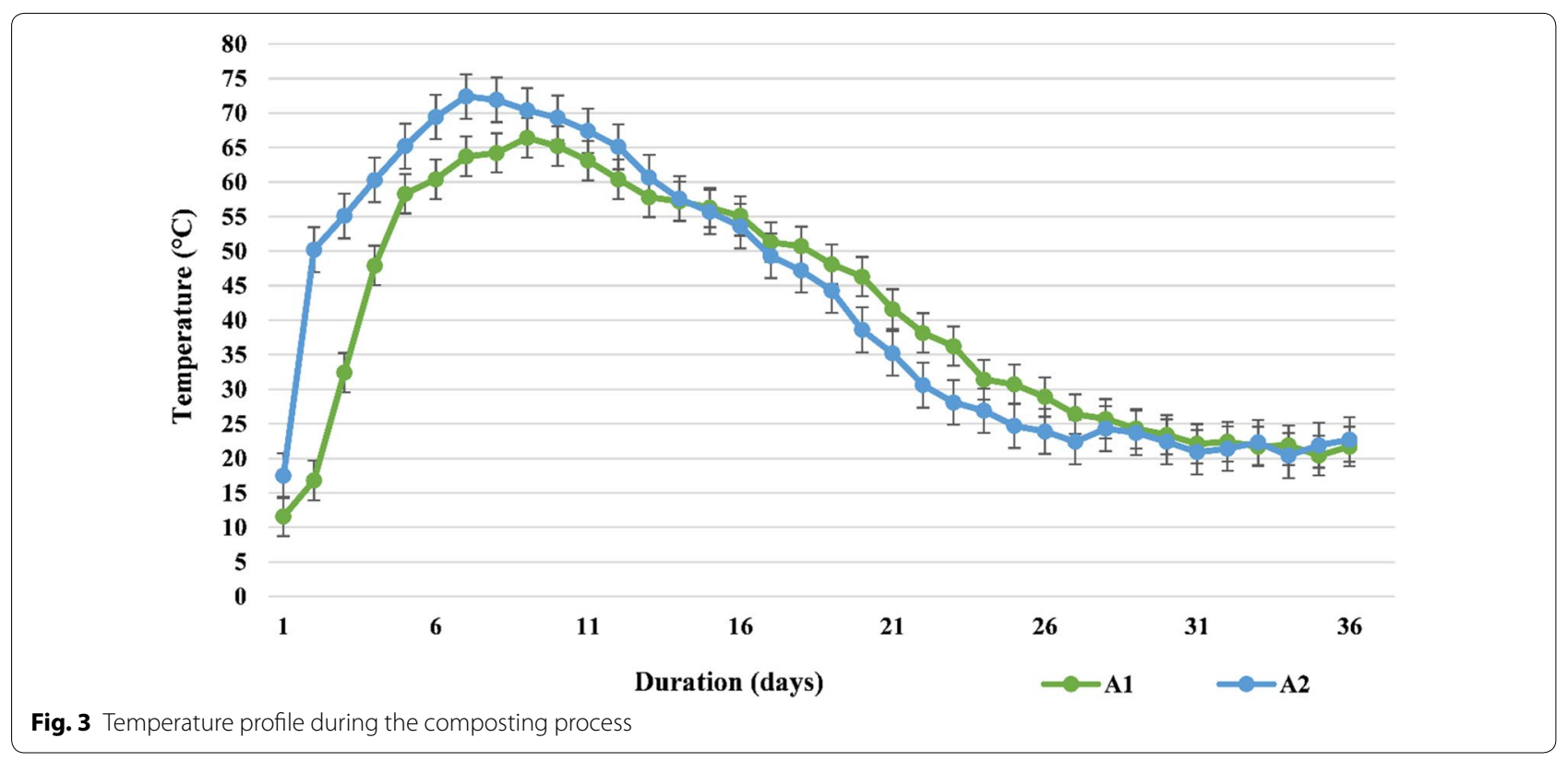


acquired from AD reactors can be used directly as a soil conditioner, it was clear that pasteurization is mandatory to ensure its purification, which is the largest energy consumer in the anaerobic digestion (AD) chain (Liu et al. 2019). Therefore, during this research work, digestate exploitation was not only beneficial for improving composting performance but also for the AD energy saving approach.

\section{Moisture monitoring profile during the composting process}

Moisture content (MC) is one of the critical factors affecting the effectiveness of a biological treatment and must be monitored systematically over the period of the process and on a regular basis. (Zakarya et al. 2018). Since the digestate was characterized by a high $\mathrm{MC}$ of about $95.9 \%$, the high water rate strongly guaranteed its sufficiency as an unconventional moisturizing agent (MA) for A2 (Kim et al. 2016). With regard to A1, the initial $\mathrm{MC}$ was modified by adding some amount of water to be within the required range of about $55-65 \%$. The initial $\mathrm{MC}$ of $\mathrm{A} 1$ and $\mathrm{A} 2$ was titrated at $68.8 \%$ and $65.8 \%$, respectively (Figs. 4, 5).

During the first two weeks, a significant decrease in $\mathrm{MC}$ occurred in $\mathrm{A} 2$, reaching 44\%, while A1 had a water content of about $54.8 \%$ at the end of the thermophilic phase. In fact, the observed decrease in MC of modified reactors compared to the unmodified one was explained by the presence of an intense microbial community provided by the digestion, which then required a large rate of water and its consumption (Makan et al.
2013). Moreover, the abundance of microorganisms in A2 was clearly predictable from the temperature profile, and thus a measure of digestate was added to set the MC at around 50\% (day 16). In terms of MA supplement, the volume of digestate added during the aerobic process was 1.2 times higher than the amount of water, ensuring an effective microbiological progress. Once the cooling phase occurred, the need for the addition of MA for different trials was not observed until the end of the treatment and a nearly stable moisture profile was recorded. At the end of composting trials, A1 and A2 were qualified by $\mathrm{MC}$ with $51.7 \%$ and $47.8 \%$, respectively. The moisture trends were consistent with the findings from Arab and McCartney (2017) for examining the effects of digestate on physical and chemical parameters.

\section{Effect of digestate addition on process stability and maturity \\ pH and C:N ratio}

As the fluctuation of temperature and moisture influenced the organic matter degradability, $\mathrm{pH}$ behaviour was linked to their tendencies during the composting process. At the beginning of the process, the $\mathrm{pH}$ of both of A1 and A2 were nearly neutral at around 7.9. However, once the temperature rose, the $\mathrm{pH}$ behaviour of $\mathrm{A} 1$ was entirely opposed to A2 until the end of the thermophilic stage. Indeed, an acidic tendency was recorded for A1 which was due to the biodegradation of carbonaceous substances and then the emission of $\mathrm{CO}_{2}$ causing an acidic $\mathrm{pH}$ (Kim et al. 2016). Contrary to $\mathrm{A} 1$, the matrix $\mathrm{pH}$ of the amended bioreactor A2 showed a progressive

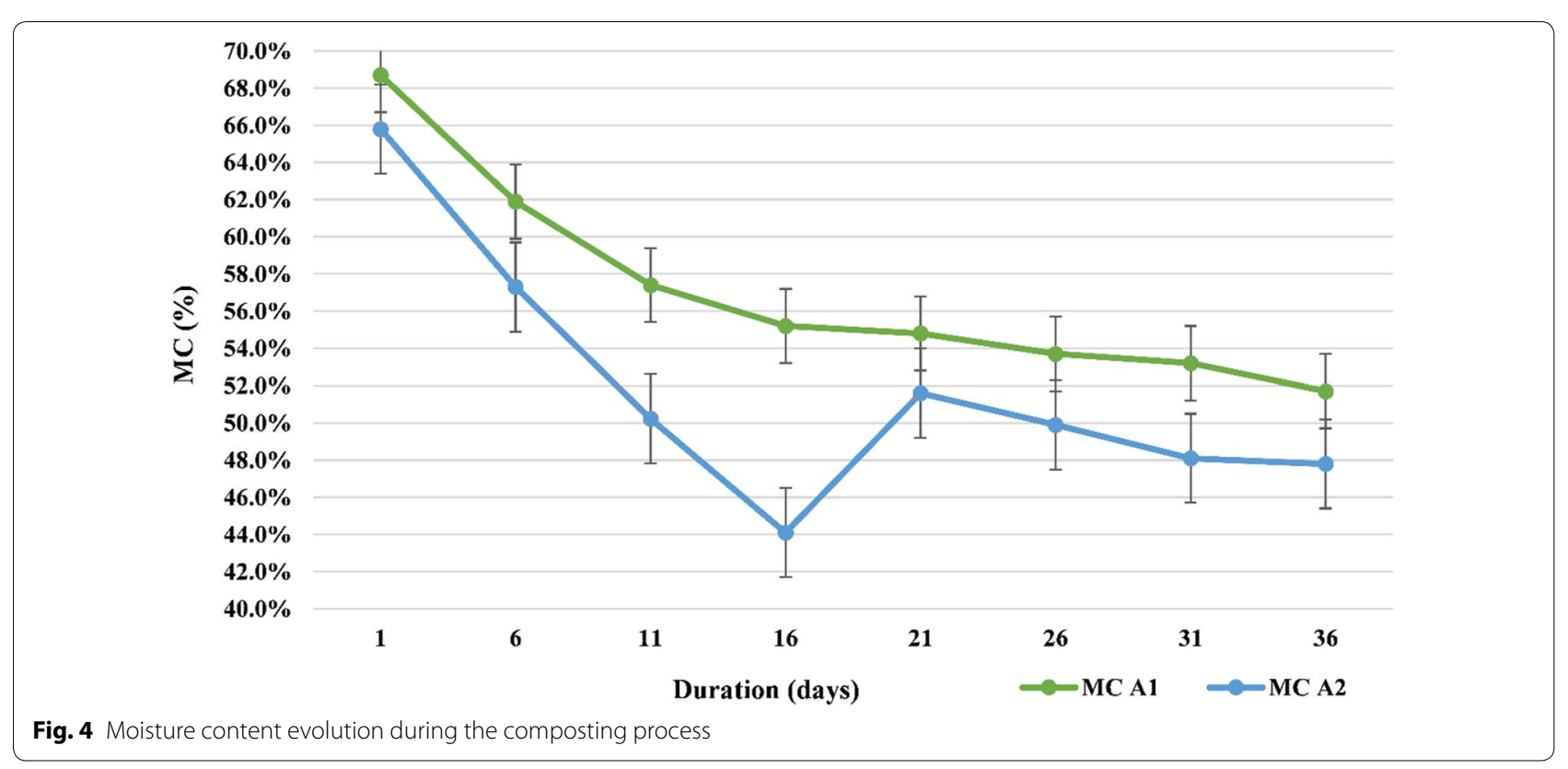




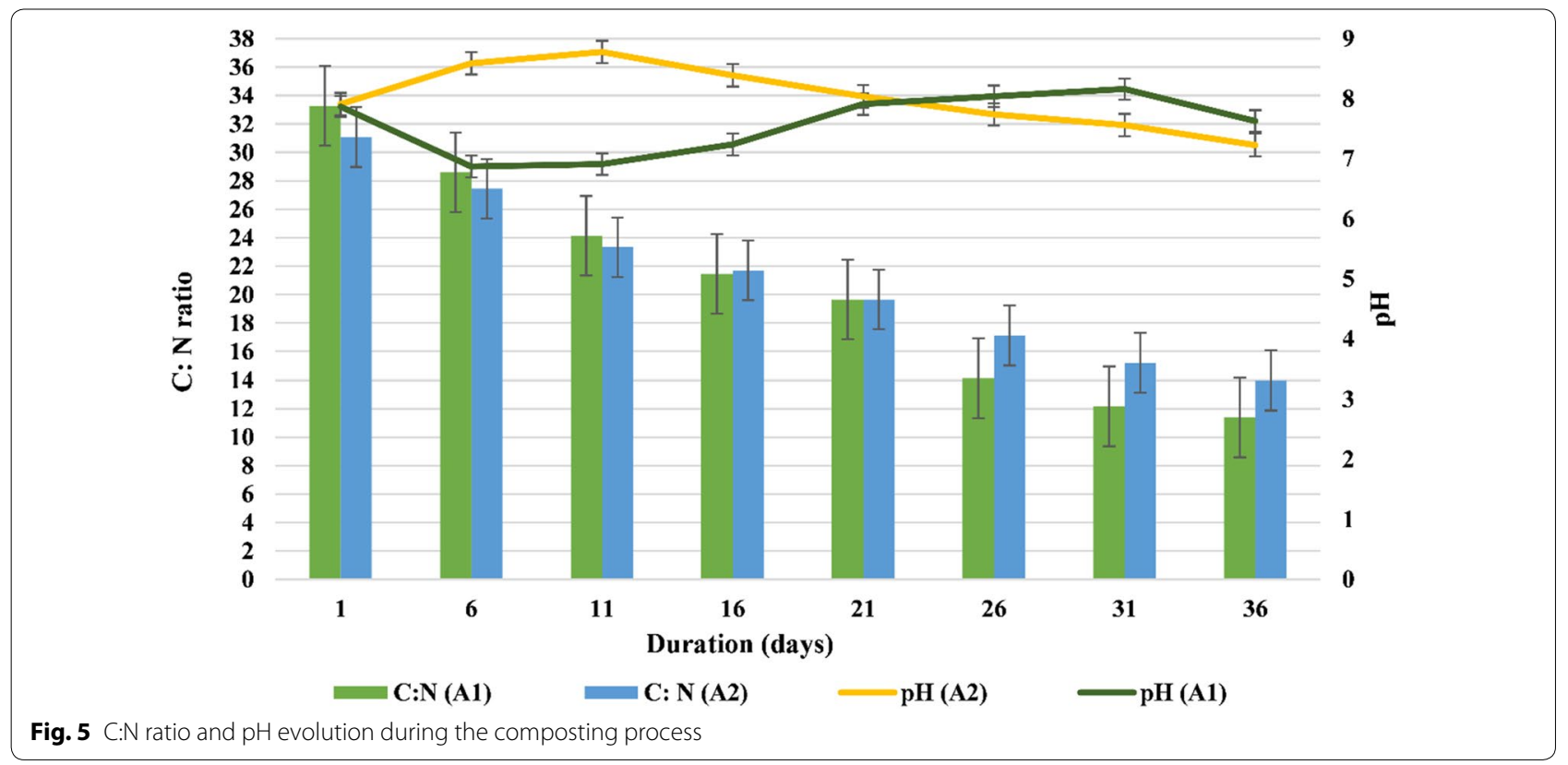

increase from 7.91 to 8.59 during the first two weeks of the process and then decreased slightly to 8.39 at the end of the thermophilic phase. It was explained by the relatively high rate of nitrogen provided by the digestate and then an intensive volatilization of the nitrogenous elements $\left(\mathrm{NH}_{3}\right)$ which was followed by a peak of $\mathrm{pH}$ at high temperatures (Zakarya et al. 2018). The findings obtained were in line with several results investigating the effect of digestate on pH behaviour (Akyol et al. 2019; Arab and McCartney 2017). As the cooling phase progressed, pH values of both A1 and A2 dropped and generally stabilized between 8 and 7. These values were within the optimum range for growing media (Hemidat et al. 2018).

$\mathrm{C}: \mathrm{N}$ ratio is one of the key monitoring factors during the composting process. It determines the level of the end product maturity and stability ( $\mathrm{Li}$ et al. 2017). It was therefore monitored over the period of the composting process to follow-up the microbial activities of both of A1 and $\mathrm{A} 2$. The initial $\mathrm{C}: \mathrm{N}$ ratio for $\mathrm{A} 1$ and $\mathrm{A} 2$ were around 33.28 and 31.07 , respectively. Once the thermophilic phase began, the tendencies of the $\mathrm{C}: \mathrm{N}$ ratio were almost the same for the amended and unamended reactors. Within the first few weeks, the C:N rate clearly decreased by around $36 \%$ for both A1 and A2 to reach 21.45 and 21.70 , respectively. In fact, the drop of $\mathrm{C}: \mathrm{N}$ ratio of the unamended reactor was a result of the decomposition of the easily degradable materials, while intensive losses in terms of nitrogen and carbon marked the amended vessels which was due to the abundance of the microbial community provided by the digestate decomposing the organic matter (Cáceres et al. 2018). Achieving the cooling stage, the $\mathrm{C}: \mathrm{N}$ ratio of $\mathrm{A} 1$ seemed to be slightly stabilized compared to A2. It was attributed to the high rate of carbonaceous components consumption during the first five weeks and lower nitrification rate compared to $\mathrm{A} 2$ which was characterized by higher nitrogenous components. Since the carbon is assumed as a source of energy, while nitrogen is required for the growth of microorganisms, a balanced utilization of nitrogenous and carbonaceous elements marked the amended reactors to obtain higher $\mathrm{C}: \mathrm{N}$ ratio during the cooling phase compared to the active one. However, both A1 and A2 reached $\mathrm{C}: \mathrm{N}$ ratio of 11.38 and 13.99 which is in line with the previous studies revealing that the suitable final C:N ratio should be less than 20 (Chaher et al. 2020b; Hemidat et al. 2018).

\section{Nitrification index (NI) and respiration activity (AT4)}

Jointly with carbon, nitrogen is the major component in the aerobic digestion as it contributes to the microorganism's occurrence and, therefore, the main progress of the process. However, the nature of the treated biomass affects the amount of nitrogen available for the microbial community and then it influences the rate of nitrogenconversion to ammonium $\left(\mathrm{NH}_{4}^{+}\right)$and nitrate $\left(\mathrm{NO}_{3}{ }^{-}\right)$ (Cáceres et al. 2016). As the ratio between $\mathrm{NH}_{4}{ }^{+}$and $\mathrm{NO}_{3}^{-}$; the nitrification index (NI) is considered as an indicator of the compost's stability (Chaher et al. 2020a), it was monitored during the composting process to evaluate the nitrogen transformation reactions. Figure 6 shows that, during the thermophilic phase, NI of the unamended reactor (A1) was considerably higher than 


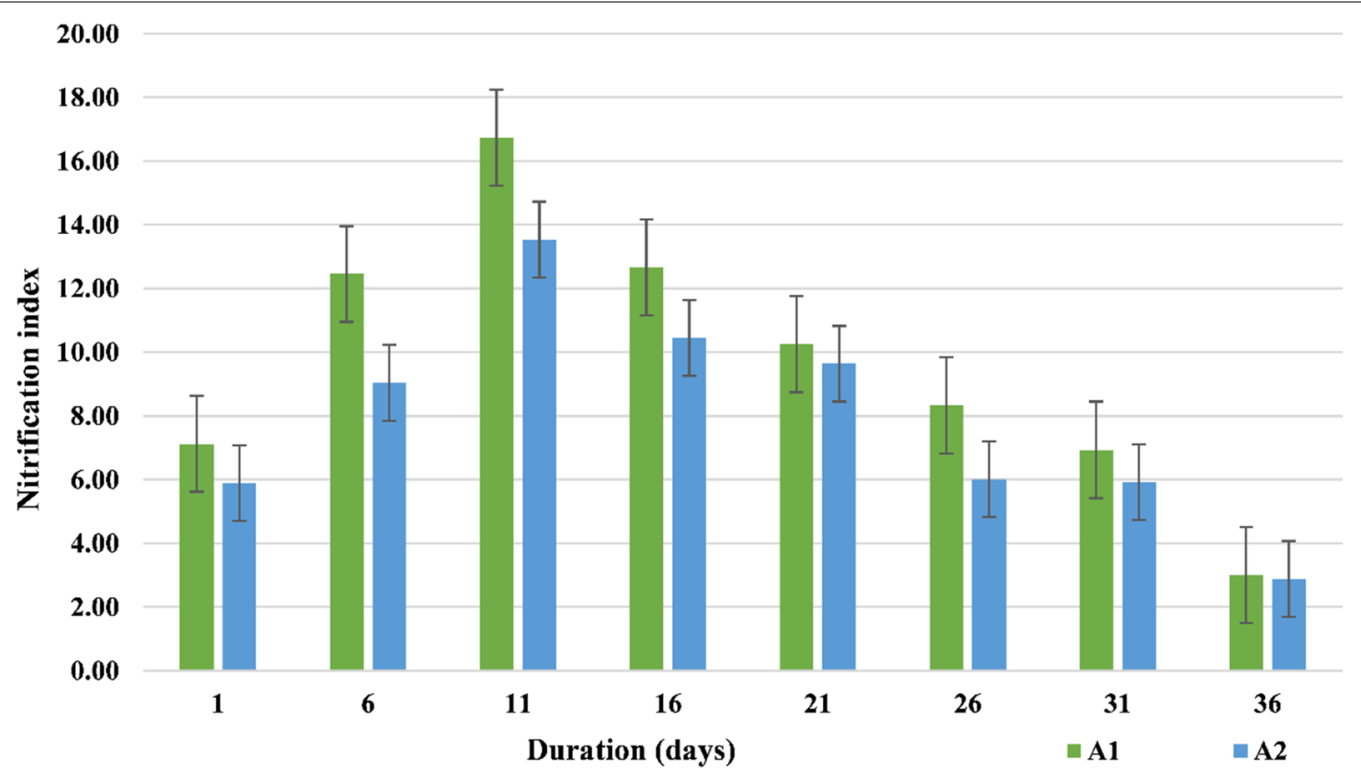

Fig. 6 Nitrification index tendencies during the composting process

the amended one (A2). It was seen that, for high temperatures $\left(>40{ }^{\circ} \mathrm{C}\right)$, NI of $\mathrm{A} 1$ varied from 7.12 to 12.66 , while it ranged between 5.89 and 10.44 for A2. The difference in terms of NI between $\mathrm{A} 1$ and $\mathrm{A} 2$ was due to the addition of digestate which is characterized by alkaline $\mathrm{pH}$ increasing $\mathrm{NH}_{3}$ volatilization potential, declining the formation of $\mathrm{NH}_{4}{ }^{+}$and raising the $\mathrm{NO}_{3}{ }^{-}$leaching (Markfoged et al. 2011). Several studies stated that, on average, a reduction of around $35-65 \%$ of the total nitrogen can be lost during the digestate composting, particularly if one of these factors existed; high $\mathrm{pH}(8-9)$, high temperatures $\left(60 \%-70{ }^{\circ} \mathrm{C}\right)$ or high airflows in conformity with the current findings (Alburquerque et al. 2012; SánchezRodríguez et al. 2018; Sangamithirai et al. 2015). Accomplishing the cooling phase, NI for both of A1 and A2 was progressively dropping to reach approximatively 3 at the end of the process. A nitrification index equal or lower than 3 indicated the maturity of the generated compost. Therefore, the end products produced from different trials were considered as finished compost at the end of the process period. Indeed, the significant decrease of NI, particularly for the amended reactor, was explained by the considerable oxidation of $\mathrm{NH}_{4}{ }^{+}$to $\mathrm{NO}_{3}{ }^{-}$covered by specific groups of bacteria and archaea. The latter is one of the most abundant microorganisms characterizing the digestate as it is essential for the anaerobic degradation of the organic matter which justified the tendencies of $\mathrm{NI}$ in A2 compared to A1.

AT4 analysis was identified to assess the stability of the final products generated from both of amended and unamended bioreactors. All of the compost samples tested ascertained their stability with reference to German Standards (Table 5) and were considered to belong to class $\mathrm{V}$.

Both A1 and A2 were characterized by low values of AT4, estimated to be 5.06 and 4.43, respectively, indicating that no more microbial activity will occur (Bazrafshan et al. 2016).

\section{Effect of digestate addition on end product quality}

Heavy metals' (HMs) measurement of the end products was based on the quality limits for agricultural use of several countries including Europe: Germany, UK, France as well as Canada and Tunisia. Table 5 summarizes the specification of seven $\mathrm{HMs}(\mathrm{Pb}, \mathrm{Ni}, \mathrm{Cu}, \mathrm{Zn}, \mathrm{Hg}, \mathrm{Cr}$ and Cd) for both of A1 and A2. It was notable that the rate of HMs for A2 was higher than for A1, especially for $\mathrm{Zn}$ which attained 80.20 for the unamended trial and $120.41 \mathrm{mg} / \mathrm{kg}$ TS for the amended one. Indeed, the significant amounts of metal components which marked A2 were predicted by the initial rate of HMs provided by the

Table 5 Classification of the compost samples according to German standards based on AT4 analysis

\begin{tabular}{|c|c|c|}
\hline $\begin{array}{l}\text { The class } \\
\text { of compost }\end{array}$ & AT4 (mg O $\mathrm{O}_{2} / \mathrm{g}$ TS) & Product description \\
\hline I & $>40$ & Compost raw materials \\
\hline$\|$ & $28-40$ & Fresh compost \\
\hline III & $16-28$ & Fresh compost \\
\hline IV & $6-16$ & Finished compost \\
\hline V & $<6$ & Finished compost \\
\hline
\end{tabular}


Table 6 The limits of total metal content ( $\mathrm{mg} / \mathrm{kg}$ total solid (TS)) regarding the standards of certain countries

\begin{tabular}{|c|c|c|c|c|c|c|c|c|c|}
\hline \multirow[t]{3}{*}{ HMs } & \multicolumn{2}{|c|}{ Samples } & \multicolumn{7}{|c|}{ Standards } \\
\hline & \multirow[t]{2}{*}{$\mathrm{A} 1$} & \multirow[t]{2}{*}{ A2 } & \multirow[t]{2}{*}{ Tunisia } & \multirow[t]{2}{*}{ UK } & \multirow[t]{2}{*}{ France } & \multirow[t]{2}{*}{ EU } & \multirow[t]{2}{*}{ Canada } & \multicolumn{2}{|c|}{ Germany } \\
\hline & & & & & & & & Class A & Class B \\
\hline Lead (Pb) & 11.93 & 14.40 & 180 & 200 & 180 & 120 & 150 & 150 & 100 \\
\hline Copper (Cu) & 28.50 & 35.01 & 300 & 200 & 300 & 300 & 400 & 100 & 70 \\
\hline Zinc (Zn) & 80.20 & 120.41 & 600 & 400 & 600 & 800 & 700 & 400 & 300 \\
\hline Nickel (Ni) & 29.90 & 32.50 & 60 & 50 & 60 & 50 & 62 & 50 & 35 \\
\hline Cadmium (Cd) & 0.26 & 1.41 & 3 & 1.5 & 3 & 1.5 & 3 & 1.5 & 1.0 \\
\hline Chromium (Cr) & 57.49 & 81.30 & - & 100 & 120 & 100 & 210 & 100 & 70 \\
\hline Mercury $(\mathrm{Hg})$ & 0.01 & 0.04 & 2 & - & - & 1 & - & 1.0 & 0.7 \\
\hline
\end{tabular}

digestate as described in Table 1 . However, despite the remarkable content in terms of HMs, A2 met all the laws applicable in several countries and it was classified as a Class B biofertilizer in reference to the German Standards (Chaher et al. 2020a). Additionally, Table 4 shows that the compost gathered from A1 was categorized as Class A based on the German limits and illustrated that both amended and unamended reactors generated high qualified end products (Table 6). Admittedly, the main organic residues exploited were characterized by low rates of HMs which affirmed the outlined quality of the biofertilizer produced by the unamended composter but, initially, a slight uncertainty arose due to the addition of the AD-liquid effluent. Indeed, several works focused on the feasibility of the digestate recovery for agricultural benefits and highlighted that the inputs of AD-effluents in terms of HMs restricted its effectiveness (Stoknes et al. 2016).

\section{Conclusion}

The experimental research was designed to create a technical approach through the combination of the two major biological treatment technologies, anaerobic and aerobic digestion. A closed cycle 'biowaste to bioenergy' treating mainly food waste (FW) was examined. To this end, four types of digestate were collected from different anaerobic reactors to be exploited as moisturizing agents (MA) to feed FW and WS in-vessel composters. Moisture content $(\mathrm{MC}), \mathrm{C}: \mathrm{N}$ ratio and heavy metals concentrations were identified as the main steering factors for the selection of the appropriate MA. Results showed that the digestate obtained from the anaerobic co-digestion of food waste and wheat straw (D3) was the most suitable option; it was characterized by the most desirable C:N ratio of around 12, a good water content of $95.9 \%$ and a low rate in terms of heavy metals concentrations. The findings revealed that the in-vessel composting process was performed under ideal conditions. Focusing on the temperature tendencies, the duration of the thermophilic phase for both the amended reactor (A2) and the unamended one (A1) was sufficient to break down any kinds of pathogens threatening the quality of the end products. When it comes to the stability and maturity indicators, several physico-chemical properties were examined. The overall decreasing profiles during the composting period for moisture, $\mathrm{C}: \mathrm{N}$ ratio as well as the nitrification index (NI) ascertained the efficiency of the AD-effluent addition to ensure a performant composting process. In addition, the respiration activity (AT4) indicated that no biological activity will take place as the compost generated from both of amended and unamended bioreactors were characterized by AT4 values lower than $6 \mathrm{mg} \mathrm{O} / \mathrm{g}$ TS meeting the German Standards in terms of stability. Regarding the end product quality, German standards were also applied to verify the final HMs concentrations, $\mathrm{A} 1$ and $\mathrm{A} 2$ produced biofertilizers of class B and class A, respectively, proving the generation of high-quality composts. Therefore, the digestate was converted from an output hardly managed to an input comfortably recovered, reducing the consumption of a conventional water source and enhancing the composting process as an efficient source of acclimatized microorganisms.

\section{Abbreviations}

SW: Solid waste; MC: Moisture content; FW: Food waste; MA: Moisturizing agent; WS: Wheat straw; CM: Cattle manure; AD: Anaerobic digestion; FM: Fresh matter; TS: Total solids; D: Digestate; HMs: Heavy metals; TC: Total carbon; TN: Total nitrogen; EC: Electrical conductivity; NI: Nitrification index; AT4: Respiration activity.

\section{Acknowledgements}

The authors express their sincere appreciation to Technical Lab for Waste Management and Bioenergy, University of Rostock, Germany, for co-funding this study. The authors are also grateful to Dr. Nils Engler for his help and support during the experimental work.

\section{Authors' contributions}

Conceptualization, NEHC; methodology, NEHC; formal analysis, NEHC, SH; investigation, NEHC, data curation, NEHC; writing — original draft preparation, 
NEHC; writing — review and editing, NEHC; supervision, AN, MC, MH and MN. All authors read and approved the final manuscript.

\section{Funding}

Open Access funding enabled and organized by Projekt DEAL. This research work was funded by "RenewValue project: Local sustainable supply of renewable energy for endangered Municipalities in arid and semi-arid Mediterranean zones".

\section{Availability of data and materials}

The data that support the findings of this study are available from the corresponding author, upon reasonable request. All data generated or analysed during this study are included in this published article.

\section{Ethics approval and consent to participate}

Not applicable.

\section{Consent for publication}

Not applicable.

\section{Competing interests}

The authors declare no conflict of interest.

\section{Author details}

${ }^{1}$ Department of Chemical and Process Engineering, National Engineering School of Gabes, University of Gabes, 6029 Gabes, Tunisia. ${ }^{2}$ Department of Biological and Chemical Engineering, National Institute of Applied Sciences and Technology, University of Carthage, 1080 Tunis, Tunisia. ${ }^{3}$ Department of Waste and Resource Management, Faculty of Agrar and Environmental Sciences, University of Rostock, 18051 Rostock, Germany. ${ }^{4}$ DBFZ German Biomass Research Center GmbH, 04347 Leipzig, Germany.

\section{Received: 19 September 2020 Accepted: 6 November 2020}

\section{Published online: 23 November 2020}

\section{References}

Abbasi S, Gajalakshmi S (2015) Disposal of municipal solid waste with in situ termireactors: proof-of-concept. Bioresour Bioprocess 2:24. https://doi. org/10.1186/s40643-015-0050-z

Abdulrahman A (2018) Solid waste management in Tunisia. EcoMENA. https ://www.ecomena.org/solid-waste-management-tunisia/. Accessed 13 Jan 2020.

Abu Hajar HA, Tweissi A, Abu Hajar YA et al (2020) Assessment of the municipal solid waste management sector development in Jordan towards green growth by sustainability window analysis. J Clean Prod 258:120539. https ://doi.org/10.1016/j.jclepro.2020.120539

Akyol Ç, Ince O, Ince B (2019) Crop-based composting of lignocellulosic digestates: Focus on bacterial and fungal diversity. Bioresour Technol 288:121549. https://doi.org/10.1016/j.biortech.2019.121549

Al Seadi T, Drosg B, Fuchs W et al (2013) 12-biogas digestate quality and utilization. In: Wellinger A, Murphy J, Baxter D (eds) The biogas handbook. Woodhead Publishing, Sawston, pp 267-301

Al-Bataina BB, Young TM, Ranieri E (2016) Effects of compost age on the release of nutrients. Int Soil Water Conserv Res 4:230-236. https://doi. org/10.1016/j.iswcr.2016.07.003

Alburquerque JA, de la Fuente C, Bernal MP (2012) Chemical properties of anaerobic digestates affecting $\mathrm{C}$ and $\mathrm{N}$ dynamics in amended soils. Agric Ecosyst Environ 160:15-22. https://doi.org/10.1016/j.agee.2011.03.007

Aparcana S (2017) Approaches to formalization of the informal waste sector into municipal solid waste management systems in low- and middleincome countries: review of barriers and success factors. Waste Manag 61:593-607. https://doi.org/10.1016/j.wasman.2016.12.028

Arab G, McCartney D (2017) Benefits to decomposition rates when using digestate as compost co-feedstock: part I — focus on physicochemical parameters. Waste Manag 68:74-84. https://doi.org/10.1016/j.wasma n.2017.07.018

Arafat HA, Jijakli K, Ahsan A (2015) Environmental performance and energy recovery potential of five processes for municipal solid waste treatment. J Clean Prod 105:233-240. https://doi.org/10.1016/j.jclepro.2013.11.071
Ardhaoui K, Bellali F, Moussa M (2019) Composting and lixiviation, case study in Médenine-Tunisia. J Res Environ Earth Sci 7:161-167

Ardolino F, Colaleo G, Arena U (2020) The cleaner option for energy production from a municipal solid biowaste. J Clean Prod 266:121908. https://doi. org/10.1016/j.jclepro.2020.121908

Asadu CO, Egbuna SO, Chime TO et al (2019) Survey on solid wastes management by composting: Optimization of key process parameters for biofertilizer synthesis from agro wastes using response surface methodology (RSM). Artif Intell Agric 3:52-61. https://doi.org/10.1016/j.aiia.2019.12.002

Awasthi SK, Sarsaiya S, Awasthi MK et al (2020) Changes in global trends in food waste composting: research challenges and opportunities. Bioresour Technol 299:122555. https://doi.org/10.1016/j.biortech.2019.122555

Aydi A (2015) Assessment of heavy metal contamination risk in soils of landfill of Bizerte (Tunisia) with a focus on application of pollution indicators. Environ Earth Sci 74:3019-3027. https://doi.org/10.1007/s1266 5-015-4332-8

Bacenetti J (2020) Editorial overview: water-energy-food nexus. Curr Opin Environ Sci Health 13:A1-A4. https://doi.org/10.1016/j.coesh.2020.04.001

Barthod J, Rumpel C, Dignac M-F (2018) Composting with additives to improve organic amendments. A review. Agron Sustain Dev 38:17. https ://doi.org/10.1007/s13593-018-0491-9

Bazrafshan E, Zarei A, Kord Mostafapour F et al (2016) Maturity and stability evaluation of composted municipal solid wastes. In: Health scope. https ://jhealthscope.com/en/articles/20165.html. Accessed 17 Mar 2020

Bhatia SK, Joo H-S, Yang Y-H (2018) Biowaste-to-bioenergy using biological methods-a mini-review. Energy Convers Manag 177:640-660. https:// doi.org/10.1016/j.enconman.2018.09.090

Cáceres R, Coromina N, Malińska Ket al (2016) Nitrification during extended co-composting of extreme mixtures of green waste and solid fraction of cattle slurry to obtain growing media. Waste Manag 58:118-125. https:// doi.org/10.1016/j.wasman.2016.08.014

Cáceres R, Malińska K, Marfà O (2018) Nitrification within composting: a review. Waste Manag 72:119-137. https://doi.org/10.1016/j.wasma n.2017.10.049

Carabassa V, Domene X, Alcañiz JM (2020) Soil restoration using compostlike-outputs and digestates from non-source-separated urban waste as organic amendments: limitations and opportunities. J Environ Manag 255:109909. https://doi.org/10.1016/j.jenvman.2019.109909

Casini D, Barsali T, Rizzo AM, Chiaramonti D (2019) Production and characterization of co-composted biochar and digestate from biomass anaerobic digestion. Biomass Convers Bioref. https://doi.org/10.1007/s13399-01900482-6

Chaher NEH, Chakchouk M, Engler N et al (2020) Optimization of food waste and biochar in-vessel co-composting. Sustainability 12:1356. https://doi. org/10.3390/su12041356

Chaher NEH, Chakchouk M, Nassour A et al (2020) Potential of windrow food and green waste composting in Tunisia. Environ Sci Pollut Res. https:// doi.org/10.1007/s11356-020-10264-7

ChenYu D, Abdullah JJ, Greetham D et al (2018) Valorization of food waste into biofertiliser and its field application. J Clean Prod 187:273-284

Du C, Abdullah JJ, Greetham D et al (2018) Valorization of food waste into biofertiliser and its field application. J Clean Prod 187:273-284. https:// doi.org/10.1016/j.jclepro.2018.03.211

Fan H, Liao J, Abass OK et al (2019) Effects of bulking material types on water consumption and pollutant degradation in composting process with controlled addition of different liquid manures. Bioresour Technol 288:121517. https://doi.org/10.1016/j.biortech.2019.121517

Ferronato N, Torretta V (2019) Waste mismanagement in developing countries: a review of global issues. Int J Environ Res Public Health 16:1060. https:// doi.org/10.3390/ijerph16061060

Franke-Whittle $\mathrm{H}$, Confalonieri A, Insam H et al (2014) Changes in the microbial communities during co-composting of digestates. Waste Manag 34:632-641. https://doi.org/10.1016/j.wasman.2013.12.009

Hemidat S, Jaar M, Nassour A, Nelles M (2018) Monitoring of composting process parameters: a case study in Jordan. Waste Biomass Valoriz 9:2257-2274. https://doi.org/10.1007/s12649-018-0197-x

Jemai I, Ben Aissa N, Gallali T, Chenini F (2013) Effects of municipal reclaimed wastewater irrigation on organic and inorganic composition of soil and groundwater in Souhil Wadi Area (Nabeul, Tunisia). Hydrol Curr Res 4:1-8. https://doi.org/10.4172/2157-7587.1000160 
Kim E, Lee D-H, Won S, Ahn H (2016) Evaluation of optimum moisture content for composting of beef manure and bedding material mixtures using oxygen uptake measurement. Asian-Australas J Anim Sci 29:753-758. https://doi.org/10.5713/ajas.15.0875

Kumar M, Ou Y-L, Lin J-G (2010) Co-composting of green waste and food waste at low C/N ratio. Waste Manag 30:602-609. https://doi. org/10.1016/j.wasman.2009.11.023

Li S, Li D, Li J et al (2017) Evaluation of humic substances during cocomposting of sewage sludge and corn stalk under different aeration rates. Bioresour Technol 245:1299-1302. https://doi.org/10.1016/j.biort ech.2017.08.177

Liu T, Zhou X, Li Z et al (2019) Effects of liquid digestate pretreatment on biogas production for anaerobic digestion of wheat straw. Bioresour Technol 280:345-351. https://doi.org/10.1016/j.biortech.2019.01.147

Mahjoub O, Jemai A, Haddaoui I (2020) Waste management in Tunisia-what could the past bring to the future? In: Negm AM, Shareef N (eds) Waste management in MENA regions. Springer International Publishing, Cham, pp 35-69

Makan A, Assobhei O, Mountadar M (2013) Effect of initial moisture content on the in-vessel composting under air pressure of organic fraction of municipal solid waste in Morocco. Iran J Environ Health Sci Eng 10:3. https://doi. org/10.1186/1735-2746-10-3

Markfoged R, Nielsen LP, Nyord T et al (2011) Transient $\mathrm{N}_{2} \mathrm{O}$ accumulation and emission caused by $\mathrm{O}_{2}$ depletion in soil after liquid manure injection. Eur J Soil Sci 62:541-550. https://doi.org/10.1111/j.1365-2389.2010.01345.x

Meylan G, Lai A, Hensley J et al (2018) Solid waste management of small island developing states - the case of the Seychelles: a systemic and collaborative study of Swiss and Seychellois students to support policy. Environ Sci Pollut Res 25:35791-35804. https://doi.org/10.1007/s11356-018-2139-3

Sánchez-Rodríguez AR, Carswell AM, Shaw R et al (2018) Advanced processing of food waste based digestate for mitigating nitrogen losses in a winter wheat crop. Front Sustain Food Syst. https://doi.org/10.3389/fsufs .2018 .00035
Sangamithirai KM, Jayapriya J, Hema J, Manoj R (2015) Evaluation of in-vessel co-composting of yard waste and development of kinetic models for co-composting. Int J Recycl Org Waste Agric 4:157-165. https://doi. org/10.1007/s40093-015-0095-1

Stoknes K, Scholwin F, Krzesiński W et al (2016) Efficiency of a novel "Food to waste to food" system including anaerobic digestion of food waste and cultivation of vegetables on digestate in a bubble-insulated greenhouse. Waste Manag 56:466-476. https://doi.org/10.1016/j.wasman.2016.06.027

Tibu C, Annang TY, Solomon N, Yirenya-Tawiah D (2019) Effect of the composting process on physicochemical properties and concentration of heavy metals in market waste with additive materials in the Ga West Municipality, Ghana. Int J Recycl Org Waste Agric 8:393-403. https://doi. org/10.1007/s40093-019-0266-6

Torres-Climent A, Martin-Mata J, Marhuenda-Egea F et al (2015) Composting of the solid phase of digestate from biogas production: optimization of the moisture, C/N ratio, and $\mathrm{pH}$ conditions. Commun Soil Sci Plant Anal 46:197-207. https://doi.org/10.1080/00103624.2014.988591

Wang H, Wang D, Zhou X (2018) Analysis on the trend of water quality in Haihe River Basin from 2005 to 2017. GEP 06:1-7. https://doi.org/10.4236/ gep.2018.611001

Xu Z, Li G, Huda N et al (2020) Effects of moisture and carbon/nitrogen ratio on gaseous emissions and maturity during direct composting of cornstalks used for filtration of anaerobically digested manure centrate. Bioresour Technol 298:122503. https://doi.org/10.1016/j.biortech.2019.122503

Zakarya IA, Khalib SNB, Mohd Ramzi N (2018) Effect of pH, temperature and moisture content during composting of rice straw burning at different temperature with food waste and effective microorganisms. E3S Web Conf 34:02019. https://doi.org/10.1051/e3sconf/20183402019

\section{Publisher's Note}

Springer Nature remains neutral with regard to jurisdictional claims in published maps and institutional affiliations.

\section{Submit your manuscript to a SpringerOpen ${ }^{\odot}$ journal and benefit from:}

- Convenient online submission

- Rigorous peer review

- Open access: articles freely available online

- High visibility within the field

- Retaining the copyright to your article

Submit your next manuscript at $\boldsymbol{\nabla}$ springeropen.com 